\title{
Hospital Chaplaincy in Half-Time
} Jana Maryšková

After the "Velvet revolution" of November 1989, after many years of unfreedom, the possibility to start in full and publicly develop their activity in a free, democratic, pluralist society opened up again before the churches. The Christian churches could thus, among other things, again fully engage in social services, culture and education, and thus cooperate with departments such as the army, the prison system, the police and the health care system.

\section{Care for persons in need as one of the realization forms of the Church}

A sphere that from the very beginning belongs to the "deepest nature of the Church" ${ }^{1}$ is care for persons in need and service to those in extreme life situations. As Pope Benedict XVI stated in his first encyclical Deus caritas est: "The Church's deepest nature is expressed in her three-fold responsibility: of proclaiming the word of God (kerygma-martyria), celebrating the sacraments (leitourgia), and exercising the ministry of charity (diakonia). These duties presuppose each other and are inseparable. For the Church, charity is not a kind of welfare activity which could equally well be left to others, but is a part of her nature, an indispensable expression of her very being." ${ }^{2}$ Service to persons in need essentially belongs to the nature of the Church, which the Pope in the second part of the encyclical calls "a community of love". This love, which - grounded in Trinitarian love - pursues the good of human beings, their advancement in various spheres of life and human activity, is the service which the Church carries out when it attends to suffering humans in their needs, including material needs. ${ }^{3}$

When Pope Benedict XVI speaks of love of neighbour as the fundamental task of the Church, he incessantly reminds the reader that loving the neighbour is impossible without loving God and vice versa. "One is so closely connected to the other that to say that we love God becomes a lie if we are closed to our neighbour or hate him altogether. (...) love of neighbour is a path that leads to the encounter with God, and that closing our eyes to our neighbour also blinds us to God." ${ }^{4}$ In the book of interviews with P. Seewald Licht der Welt Benedict XVI quotes St. Augustine: "The history of the world is a struggle between two forms of love: love of oneself - up to destroying the world; and love for the other - up to renouncing oneself." ${ }^{\prime 5}$ It is precisely God who loves us first. That is why we are also able to respond with love. It manifests itself in service to persons in need not only within the Church, not only to those 'who are of the household of faith' (Gal 6:10), but "caritas-agape extends beyond the frontiers of the Church. The parable of the Good Samaritan remains as a standard which imposes universal love towards the needy whom we encounter 'by chance' (cf. Lk 10:31), whoever they may be."6 "With his conception of diakonia as 'assisting love'

1 BENEDIKT XVI., Deus caritas est, Praha: Paulínky, 2006, art. 25. Further in text only DCE and the relevant section number.

2 DCE 25.

3 Cf. DCE 19.

4 DCE 16.

5 BENEDIKT XVI. - Peter SEEWALD, Licht der Welt: Der Papst, die Kirche und die Zeichen der Zeit, Freiburg im Breisgau:

Verlag Herder GmbH, 2010, p. 79.

6 DCE 25. 
the Pope significantly contributed to understanding diakonia as a constitutive element of the Church."

\section{Practical realization of service to persons in need}

\subsection{Establishing spiritual service in the army, prison system, with the Police of CR and} Firefighters Corps of CR

The churches, aware of their common mission to serve persons in need and in difficult life situations, to witness to Christian faith and hope, gradually signed agreements concerning spiritual care of soldiers, prisoners, members of the Police of CR and Firefighters Corps of CR with the relevant departments. The first one to be signed in 1998 was the agreement between the Ecumenical Council of Churches (ERC) and Czech Bishops' Conference (ČBK) Contract concerning the Conditions of Establishment and Activity of Spiritual Service in the Resort of the Ministry of Defence, part of which is Agreement of Cooperation between the Ministry of Defence, ERC and CBK. Among other things, the Agreement defines spiritual service, the status of military chaplains, their scope of employment, their appointment and suspension, education, provisions for the activity of military chaplains, and others. ${ }^{8}$

In August 2008, by ordinance no. 41 of the Director General of the Prison Service of CR, the Agreement on Spiritual Service between representatives of ERC, ČBK and the Prison Service was declared, with the goal "to stipulate in accordance with legal norms the conditions of mutual cooperation and help (...) in spiritual and educational work with persons accused of crimes, convicted of crimes and those in security detention."

Then in 2011 ERC, ČBK and the Ministry of Interior of CR signed the Agreement on the Participation of Persons Performing Spiritual Service in the System of Providing Post-Tranmatic Intervention Care, where the goal of the Agreement is "to regulate the providing of posttraumatic intervention care to members of the Police Force of CR and Firefighters Corps of $\mathrm{CR}$, employees of the Police Force of CR and Ministry of Interior, their family members, close persons and persons from the public, i.e., the victims of extraordinary events or crimes, by persons engaging in spiritual activity." ${ }^{10}$ Similarly in 2006 an agreement was signed between ERC and CBK concerning spiritual care in the health care system, discussed in more detail below.

\subsection{Institution and gradual implementation of spiritual service in the health care system}

Care of the ill is present throughout the Church's history; following the example of Jesus, who was compassionate with the suffering, cured the ill and himself "has borne our griefs and carried our sorrows; yet we esteemed him stricken, smitten by God, and afflicted. But he was pierced for our transgressions; he was crushed for our iniquities" (Isa 53:4-5), the

7 Michael MARTINEK a kol., Praktická teologie pro sociální pracovníky, Praha: JABOK, 2008, p. 65.

8 Cf. (C) Contract between the Ecumenical Council of Churches and Czech Bishops' Conference (on-line), at: http://www.cirkev. cz/res/data/004/000523.pdf, retrieved May 28th, 2015.

9 (C) Collection of Ordinances of the Director General of the Prison Service of the Czech Republic. Ordinance no. 41, whereby The Agreement on Spiritual Service is proclaimed (on-line), at: http://www.vscr.cz/client_data/1/user_files/19/file/PDF/ Duchslužba/DOHODA_komplet.pdf, retrieved May 28th, 2015.

10 (C) Agreement on the Participation of Persons Performing Spiritual Service in the System of Providing Post-Traumatic Intervention Care (on-line), at: http://spcp.prf.cuni.cz/dokument/dohoda-posttramuatickapece.pdf, retrieved May 28th, 2015. 
Church "visits the ill, brings them the encouragement of sacramental anointing and the Eucharist, accompanies them with prayers in their illness and when they are leaving this world commends them to God. When the churches engage in care of the ill, they thereby serve Christ himself (cf. Mt 25:39-40), fulfil his command to care for the ill (cf. Mk 16:18)"11 and by this service (diakonia), which is an expression of faith and love (caritas), follow Jesus Christ, "for in Christ Jesus neither circumcision nor uncircumcision counts for anything, but only faith working through love" ( $\mathrm{Gal}$ 5:6).${ }^{12}$ Continuity of this care had not been altogether broken even at the time of the communist regime, but it was significantly restricted and made more difficult. Visits of ill persons in health care establishments could only take place for two hours on Wednesday and on Sunday and the presence of the priest was usually secret, as priests themselves testify. "Visits of priests in hospitals at beds of long-term patients and those who were dying had to take place in secret, as if they were a merely private matter." 13 Although after the fall of the totalitarian regime nothing prevented introducing spiritual care in the health care system - as it happened in the case of the departments mentioned above -, its systematic introduction and commissioning of hospital chaplains to health care facilities has only been a matter of the last few years.

However, already since 1997 clinical pastoral care has been provided ${ }^{14}$ in the General University Hospital in Prague, where in 2006 its Director and the Advisory Board of the Dean of the 1st Medical Faculty of the Charles University approved the Unit of Clinical Pastoral Care as part of the Oncological Clinic, whose activity was extended to the 1 st Internal Clinic of Hemato-Oncology in 2008. This Unit is an active member of the European Network of Hospital Chaplains and besides supra-confessional clinical pastoral care also takes part in the preparation of a number of formational educational meetings of pastoral workers from health care facilities in Czech Republic and Slovak Republic. ${ }^{15}$

In November 2006 the Agreement on Spiritual Care in the Health Care System between the Crech Bishops' Conference and the Ecumenical Council of Churches in the Czech Republic was signed with the goal of aiding suffering persons in difficult life situations regardless of their creed. ${ }^{16}$ In December 2011 a Supplement was added to the Agreement, which "specifies and regulates the arrangements contained in the Agreement and its Appendices no. 1 and 2". ${ }^{17}$ According to this Agreement hospital chaplains and volunteers are commissioned to work in health care facilities, where a mutual agreement has been made between the heath care facility and a representative of ČBK or ERC. The health care facility and the commissioning church then

11 Obrady pomazání nemocných a péče o nemocné, Kostelní Vydři: Karmelitánské nakladatelství, 2002, p. 5.

12 Cf. Michael MARTINEK a kol., Praktická teologie pro sociální pracouníky, p. 40.

13 Dominik DUKA - Milan BADAL, Bílá kniba církve s černou kapitolou: 20 let svobody 1989-2009, Kostelní Vydří: Karmelitánské nakladatelství, 2009, p. 51.

14 Clinical pastoral care is part of the overall care for the patient and can be defined as "care for the existential, spiritual and religious needs (questions, difficulties, problems) of the ill and those taking care of them (medical staff, relatives and friends). It fully respects the autonomy of the ill persons and their personal values deriving from their beliefs and preferred culture. In the concept of approaching the total pain it contributes primarily by reducing existential anxiety to improving or maintaining the quality of life of the patient and her near ones.” Marie OPATRNÁ, Etické problémy v onkologii, Praha: Mladá fronta, 2008, p. 86. 15 Cf. ibid, p. 91.

16 (C) Agreement on Spiritual Care in the Health Care System between the Czech Bishops' Conference and the Ecumenical Council of Churches in the Czech Republic (on-line), at: http://tisk.cirkev.cz/res/data/008/001107.pdf?seek=1164034509, retrieved May $29^{\text {th }}, 2015$.

17 (C) Supplement no. 1 to the Agreement on Spiritual Care in the Health Care System between the Czech Bishops' Conference and the Ecumenical Council of Churches in the Czech Republic (on-line), at: http://www.ado.cz/kaplan/dodatek_1.pdf, retrieved May $29^{\text {th }}, 2015$. 
make their own agreement regulating the activity of the hospital chaplain in the particular facility, where the manner of commissioning and time of its duration is determined by the individual churches according to their regulations. ${ }^{18}$ However, as D. Němec states, "practice has shown that implementing the Agreement of 2006 encountered great difficulties, both in the sphere of the manner of commissioning the hospital chaplains and in fulfilment of the qualification expectations for hospital chaplains and volunteers. As a result of these difficulties, by 2011 not even one (sic!) commissioning of a hospital chaplain or volunteer, realized according to the arrangements of the Agreement, had taken place." ${ }^{19}$ Supplement no. 1 to the Agreement on Spiritual Care in the Health Care System therefore emends some of the arrangements of the Agreement and newly states that "hospital chaplains and volunteers are commissioned for work in health care facilities, where mutual agreement has been made between the health care facility and a church operating in the place where the facility is located, whereby the commissioning church can represent several churches with respect to the health care facility, based on mutual agreement. The health care facility and the commissioning church then make a written contract regulating the activity of the hospital chaplain in the particular health care facility." ${ }^{20}$ The Supplement in section IV, point 2 also specifies a transitional period of seven years starting with the date of effect of the Supplement to develop an educational system and meet qualification requirements. Over this transitional period it is possible to distinguish between hospital chaplains in a narrow sense of the word and pastoral assistants, within the member churches of ČBK and ERC (especially in the Catholic Church). In this period, chaplains in the narrow sense of the word, i.e., those who have completed a theological education at master's level, direct the work of pastoral assistants and volunteers. However, such distinction is an internal matter of the churches and in contact with the health care facilities the established distinction "hospital chaplain" and "volunteer in spiritual care" is still used. ${ }^{21}$ Based on this Agreement and its Supplement hospital chaplains have gradually begun to work in various places of the Czech Republic; the number of health care or social facilities in which hospital chaplains are active is well illustrated by a map of these facilities at the website of the Catholic Association of Hospital Chaplains in the Czech Republic, showing the activity of Catholic chaplains as well as chaplains from churches associated under ERC. ${ }^{22}$

Although chaplaincy in hospitals and social care facilities gradually became established, there was for a long time no umbrella organization associating the chaplains, providing for their meetings and exchange of practical experience, informing about hospital chaplaincy abroad and organizing formational educational courses. On the initiative of Marie Opatrná the Czech Society for Clinical Pastoral Care (ČSKPP) was founded in 2009. In February 2009 the founding meeting of ČSKPP took place under the patronage of MUDr. Z. Roithová, whereby ČSKPP became member of the Czech Medical Society of J. E. Purkyně (ČLS JEP) as a volunteer association of physicians, non-medical professionals (hospital chaplains, theologians) and other health care workers interested in clinical pastoral care.

18 Cf. (C) Agreement on Spiritual Care in the Health Care System.

19 Damián NĚMEC, Právní zakotvení pastorační péče v necírkevních zdravotnických zařízeních v České republice, in:

Revne církevníbo práva, Praha: Společnost pro církevní právo, 2015, p. 60.

20 (C) Supplement no. 1 to the Agreement on Spiritual Care in Health Care.

21 Ibid.

22 (C) Katolická asociace nemocničních kaplanů v ČR (on-line), at: http://kaplan-nemocnice.cz/, updated on May 29 $9^{\text {th }}, 2015$, retrieved May 29 2015. 
This professional society, ecumenically based, set as its goal sponsoring interdisciplinary dialogue between physicians on the one hand and pastoral workers in health care facilities and theologians on the other. But it did not succeed to meet this goal, among other things due to the non-existence of a clear and unified conception of providing spiritual care in the health care system. The role of the society as mediator and professional medical consultant thus turned out to be problematic. In May 2011 a proposal for its dissolution was made and in June 2011 the society was dissolved. ${ }^{23}$

Important change took place in 2011 and 2012 when two associations were founded. In May 2011, following the initiative of V. Vurst, the Association of Hospital Chaplains (ANK) was founded "for the purpose of coordination, edification, education and care of chaplains active in hospitals", ${ }^{24}$ whose founding members' meeting took place in June 2011. Approximately a year and a half later, on October $2^{\text {nd }}, 2012$, the Catholic Association of Hospital Chaplains in the Czech Republic (KANK v ČR) was ceremonially established at Velehrad, in presence of representatives of ČBK, ERC and ANK..$^{25}$ The foundation of these two associations thus solved the issue of the missing umbrella professional organization, not only to associate hospital chaplains, but also to inform hospitals, the broad public and persons interested in chaplaincy service of their existence and work and at the same time to facilitate further education of chaplains.

In the already mentioned sphere of chaplains' education positive development also occurred. From 2005 formational educational meetings regularly took place, started by four women - M. Opatrná and N. Mandysová from the Czech Republic and L. Ileninová and M. Prášilová from the Slovak Republik, whose main motivation was the need for education and passing on experience with the goal of creating a certain analogy to the "consultations" held since 1990 by the European Network of Hospital Chaplaincy. These formational educational meetings were organized by the Oncological Clinic of the General University Hospital in Prague and 1st Medical Faculty of the Charles University, in particular the Centre of Integrated Oncology and Palliative Care. ${ }^{26}$ A further initiative followed in 2007 when the Protestant Theological Faculty of the Charles University in Prague launched a ten month pilot project called Hospital Chaplain, intended for future workers in spiritual service in the health care facilities of CR, prepared by a collective of workers of the Protestant Theological Faculty and $1^{\text {st }}$ and $2^{\text {nd }}$ Medical Faculty of the Charles University. ${ }^{27}$

A third initiative in the sphere of education arose at the Faculty of Theology of the University of South Bohemia in České Budějovice. In March 2011, on the initiative of alumni of the faculty and by agreement with the faculty's dean and vice-dean, an introductory information and discussion meeting of representatives of the Christian Police Association, representatives

23 Note: It is no longer possible to cite the society's website since it has been terminated, but the author of this paper was member of the society while it existed.

24 (C) Association of Hospital Chaplains (on-line), at: http://www.nemocnicnikaplan.cz/rubrika/2-Kdo-jsme/index.htm, retrieved May $29^{\text {th }}, 2015$.

25 Cf. (C) Hospital Chaplains in the Archdiocese of Olomouc (on-line), at: http://www.ado.cz/kaplan/setkani_knk.htm, retrieved May $29^{\text {th }}, 2015$.

26 Cf. C Marie OPATRNÁ, Re: Velehradská setkání (elektronická pošta). Message to: Jana Maryšková, June 28h, 2011. Personal communication, quoted with author's consent.

27 Cf. (C) Evangnet. Kutz ETF - Nemocniční kaplan (on-line), at: https://www.evangnet.cz/119-kurz_etf_nemocnicni_kaplan, retrieved June $1^{\text {st }}, 2015$. 
of military, prison and hospital chaplains, representatives of the Firefighters Corps and PostTraumatic Intervention Team of CR took place with the goal of formulating the requirements for education issuing from the practice in the individual spheres, the possibilities and forms of education, and assessing to what extent the individual spheres overlap from the point of view of education and to what extent they are specific. The result were two courses offered by the Faculty of Theology of the University of South Bohemia as part of lifelong education courses in 2012/2013, intended for persons working in assisting professions in the broadest sense of the word (social workers, physicians and medical workers, teachers and educators, chaplains, clerics, firefighters, police officers, prison service). It was a qualification course entitled Identity of a Serving Christian and an extending course entitled Intercultural Communication and Religious Studies. ${ }^{28}$

The Protestant Theological Faculty later followed up on its pilot project and in 2014/2015 offered the qualification course Hospital Chaplain ${ }^{29}$ as part of lifelong education courses. A similar course is also given by the Sts. Cyril and Methodius Faculty of Theology of the Palacký University in Olomouc, also as part of lifelong education courses. ${ }^{30}$ The Catholic Association of Hospital Chaplains in CR organizes state-wide gatherings of hospital chaplains, educational courses and conferences, and thereby contributes to further education of persons already working as hospital chaplains. ${ }^{31}$

\subsection{Missing legislative framework}

Although the number of hospitals and social services facilities in the Czech Republic in which, as part of increasing the quality of patient care, the service of hospital chaplains is introduced is gradually growing and although the churches themselves in a substantive measure participate in initiating and introducing it, there is as yet no legislative framework for the work of hospital chaplains and their position in health care facilities. While in the case of agreements on spiritual service in the army, in the prison service and with the Police of CR the contracting parties always were representatives of ERC, ČBK and the given department, in the case of spiritual care in the health care system, as stated above, the agreement is made between a facility of health or social care on the one hand and a church operating in the place where the facility is located on the other. The Ministry of Health Care is not a contract partner here. J. Odrobiňák believes that "a real interest in satisfying the spiritual needs of the ill can only be raised by pressure on the legislator that beside army or prison chaplains hospital chaplains also become commonplace". ${ }^{32}$

In the Czech Republic the Law on Health Services no. 372/2011 Sb., as amended by Law no. $167 / 2012$ Sb., in $\mathbb{S} 28$, par. 3 letter j) sets down the patient's right to spiritual service: "Patients have the right to receive in the health care facility of ward care or one-day care spiritual care and spiritual support from clerics of churches and religious societies registered in the

28 Note: It is no longer possible to cite the website, but the author of this paper personally took part in this information and discussion meeting.

29 Cf. (C) Evangelická teologická fakulta, Univerzita Karlova v Praze. Kurzy celoživotního vzdělávání (on-line),

at: http://web.etf.cuni.cz/ETF-32.html, retrieved June $1^{\text {st }}$, 2015.

30 Cf. (C) Cyrilometodějská teologická fakulta Univerzity Palackého v Olomouci. Celoživotní vzdělávání (on-line),

at: http://www.cmtf.upol.cz/skupiny/zajemcum-o-studium/celozivotni-vzdelavani/\#c33315, retrieved June 1 2015.

31 Cf. (C) Catholic Association of Hospital Chaplains in Czech Republic.

32 Jaromír ODROBIŇÁK, Spirituální péče v nemocnicích, Universum 3/2010, p. 5. 
Czech Republic or from persons commissioned to spiritual activity (further only "clerics") in accordance with the inner regulations and in a manner that does not violate the rights of other patients and with respect to their state of health, unless another legal regulation states otherwise; the visit of a cleric cannot be refused to a patient in case of a threat to life or serious health damage." ${ }^{33}$ No other legislative regulation concerning in particular hospital chaplains, their activity in health care facilities and the realization of spiritual care in the sphere of health care in the Czech Republic has yet been passed.

The Ministry of Health Care of CR has begun to take steps in this direction that should bring about the necessary change. In 2011 the former Minister of Health Care L. Heger met the Prague Archbishop D. Duka, chairman of ČBK, and Joel Ruml, then chairman of ERC, concerning spiritual service in hospitals. At the meeting the parties agreed that the Ministry of Health Care of CR will assume official patronage of spiritual service in hospitals and in cooperation with the churches will specify the legislative grounding of the presence of hospital chaplains in health care facilities. ${ }^{34}$ In 2012 L. Heger visited the Vatican where he, among other things, conferred on spiritual service in health care facilities and the possibility of spiritual service not only for patients, but also for the medical personnel. As the Minister stated: "Doctors and nurses are subject to stress, spiritual workers could make their mission easier by being near in health care facilities." 35 "Heger's department was to provide a certain framework for the situation of chaplains, bringing them to an appropriate position among other workers in the health care system. The first occasion to this was to be the prepared law on non-medical workers." ${ }^{36}$ But when the government whose member L. Heger was fell in 2013, it was no longer possible to bring these steps in practice. The present Minister of Health Care S. Němeček has as yet not declared any similar preparatory steps aimed at legislative grounding of the work and position of hospital chaplains.

We can thus regard as partial success that the vocation "chaplain" is listed in the Catalogue of Jobs - Placement according to Vocation and Payment Classes in Public Services and Administration valid since October 1st 2010 , which stipulates the allocation of jobs to payment classes and according to kind to vocation. This catalogue of jobs was published by the Ministry of Work and Social Affairs of CR at its website and under the code 1.05.04 it lists chaplain, together with placement in the appropriate payment class and description of work. ${ }^{37}$ According to this catalogue of jobs a chaplain "provides spiritual services in prison, health care, social and other facilities including contact with the individual churches"; in a higher payment class the contents of his work is "methodological and coordinating activity in the sphere of spiritual service in prison, health care, social and other facilities, further coordination of regional issues of spiritual service in connection to the related branches" and finally in the highest payment class a chaplain engages in "creating fundamental conceptions of spiritual service and its organization in prison, health care, social and other facilities, further system

33 (C) Ministry of Health Care CR. Law on Health Services no. 372/2011 Sb. amended by Law no. 167/2012 Sb. (on-line), at: http://portal.gov.cz/app/zakony/zakon.jsp?page=0\&nr=372 2F2011\&rpp=15\#seznam, retrieved June $2^{\text {nd }}, 2015$.

34 (C) Ministerstvo zdravotnictví ČR. Ministerstvo zdravotnictví podpoří nemocniční kaplany (on-line), at: http://www.mzcr.cz/ dokumenty/ministerstvo-zdravotnictvi-podpori-nemocnicni-kaplany_5683_2160_1.html, retrieved June $2^{\text {nd }}$, 2015.

35 (C) Christnet.cz. Heger ve Vatikánu hovořil o možnosti služeb duchovních pro lékaře (on-line), at: http://www.christnet.cz/ magazin/zprava.asp?zprava=23701, retrieved June $2^{\text {nd }}, 2015$.

36 Ibid.

37 Cf. @ Ministerstvo práce a sociálních věcí ČR. Nařízení vlády č. 222/2010 Sb., o katalogu prací ve veřejných službách

a správě (on-line), at: http://www.mpsv.cz/files/clanky/8980/Katalog_praci_UZ_1_10_2010.pdf, retrieved June 3rd, 2015. 
coordination of spiritual service with overlap to related social areas and synchronization of spiritual activities at international level with participation in system solution of European multicultural issues" ${ }^{38}$ In this way chaplains now belong in the budget sphere of the state and the term "chaplain", that has for already several years been commonly used in the army and prison service, thereby obtained the necessary professional framework specifying the work contents, placement in payment class according to complexity, responsibility and difficulty and incorporation according to kind of vocation also in the sphere of hospital care (as well as hospice care etc.).

\section{What legislative regulation could and should bring}

\subsection{Official position of chaplain in health care facilities, creation of so-called systemized position}

As the right of patient to spiritual service is grounded in the legislature, so carrying out spiritual service should also be legislatively regulated and acknowledged, in order that its legislative grounding would enable not only carrying it out, but would also meet other requirements linked to providing it and necessary for its realization, such as e.g. granting suitable spaces for conversations and for worship. The as yet missing legislative regulation should first of all make possible that the position of chaplains in health care facilities is official, as it is in the case of army and prison chaplains. In the health care facilities in the Czech Republic the situation is made difficult by the fact that in most cases the chaplains are not employees of the health care facility in question, but of the church that commissions them for service in this facility. Unlike e.g. in case of clinical psychologists, a so-called systemized position is as yet not universally and uniformly created for hospital chaplains in health care facilities, i.e., stating the expertise, its number, name and limitation (= the number of services that can be reported and will be covered by the health insurance company in accordance with coverage regulation) in the List of Health Services. For health care facilities, especially if there is a greater number of chaplains, it would certainly be economically more advantageous if the services of chaplains were covered by insurance companies, not from the health care facility's profit.

\subsection{Status of worker in health care}

The legislative regulation should grant the status of workers in health care to hospital chaplains, for several reasons:

incorporating chaplains in the work team brings a new view of their work and clarification of their competency and professional profile. The work of hospital chaplains differs from the work of psychologists, social workers or volunteers, although it can share a number of points with them, which often brings along a number of misunderstandings. The situation can further be complicated by the fact that, unlike e.g. army chaplains, a hospital chaplain need not be a cleric, but also a lay person. As part of the work team chaplains will not be viewed as heterogeneous elements from the outside by the medical personnel, as external missionaries of churches, but as colleagues, which also brings a shift in understanding their activity in the health care 
facilities and a wholly fundamental change in perceiving pastoral care as an essential and integral part of the health care facility's overall care of patients;

- if chaplains are members of the work team of physicians, nurses and other medical workers, they have the right to inspect medical documentation, take part in physicians'meetings or visitations and thus obtain more complex information on the patient;

- if hospital chaplains are members of the work team, it means among other things that they will automatically have information that as external workers they either do not have or receive with delay (information about personnel changes, organizational, operative and other information);

- legislative regulation bringing chaplains the status of workers in health care would allow for their easier incorporation in so-called multidisciplinary team. Abroad the service of hospital chaplains has for a number of years been provided as part of multidisciplinary medical teams - "the present multidisciplinary team in the hospitals of Europe, USA, Canada and Australia includes not only physicians, nurses, a psychologist, a social worker (...) but also a hospital chaplain." 39 "Including the chaplain in the team derives from the needs of both acute medicine and palliative care (...), abroad chaplains are therefore members of both intensive care teams and palliative care teams." ${ }^{40}$ It is team cooperation of representatives of medical and nonmedical professions with the goal of realizing "integrated complex care preventing and ameliorating all aspects of suffering" 41 and solving health, social and other problems important for the patient.

Sr. A. Pintířová also speaks of her experience in this respect for the Medical Daily of February 1"st 2015: "Hospital chaplain is a profession that should normally belong in the nursing team. Precisely because medical science is advancing so fast it is becoming ever more evident that the spiritual aspect of the human in many respects affects the physical aspect and therefore all people have spiritual needs, not only the faithful. (...) Unfortunately, chaplains are as yet not an integral part of the team. Already twenty years ago I took part in a seminar on spiritual care in Germany (...). In the seminar various casuistries of accompanying the dying were discussed. One hospital chaplain from a university hospital began with the words: 'They called me immediately to the intensive care unit that they had brought a patient with cancer of the lungs (...).' And then she recalled how some were taking care of the inhalation mechanism and infusions and she was taking care that the patient and his family prepare for the end of his life. It seemed to me as a vision from faraway future. The lecturer then told me: 'Wait for ten years, it took time here as well.' It has already been twenty years, but I am not sure that our mentality has changed." 42

39 (C) Marie OPATRNÁ, Rozšířená zpráva z konference Lisabon 2006 (on-line),at: http://ckpp.wz.cz/view.

php?cisloclanku=2006100001, retrieved June $2^{\text {nd }}, 2015$.

40 (C) Marie OPATRNÁ, Klinická pastorační péče a její poskytovatel (on-line),

at: http://ckpp.wz.cz/view.php?cisloclanku=2006100002, retrieved June 2 $2^{\text {nd }}, 2015$.

41 Marie OPATRNÁ, Etické problémy v onkologii, p. 44.

42 (C) Angelika PINTÍŘOVÁ, Nemocniční kaplan by měl být členem ošetřovatelského týmu, ř́ká sestra Angelika, Zdravotnický deník (on-line), at: http://www.zdravotnickydenik.cz/2015/02/nemocnicni-kaplan-by-mel-byt-clenem-osetrovatelskeho-tymu -rika-sestra-boromejka-angelika/, retrieved June $2^{\text {nd }}, 2015$. 


\subsection{General and special standards of education}

Legislative regulation concerning spiritual care in facilities where hospital chaplains are active should also unambiguously state the qualification requirements for this care. In order that future as well as current chaplains can take quality preparation for their future vocation as well as extend their knowledge and skills while already performing it, it is necessary to create certain standards of education, stipulate who will provide this preparatory and subsequent education, and by agreement with health care facilities also stipulate in which of them future chaplains supervised by their more experienced colleagues could obtain work experience and in what extent. The required qualification presuppositions should thus be clearly and unambiguously stipulated also for the time after the transitional period of seven years, so that this legal regulation can serve as guidance both for facilities of health and social care and for the chaplains themselves.

The above stated qualification requirements are linked to the question whether the "general" standards of education ought not to be extended by supplementary special requirements for the education of chaplains active in pastoral care of groups of patients with specific needs (with impaired vision, impaired hearing, deaf-blind patients, other groups of patients).

\subsection{Establishing the position of Head Hospital Chaplain}

If the Ministry of Health Care becomes partner of the churches, a person or persons should be appointed to coordinate and unify the activity of both parties. The structure of the service of head chaplain already exists in the army and in the Prison Service of CR and it would be advantageous to transfer it also to the civil sector. A possible version is that Head Hospital Chaplain will be employed by the Ministry of Health Care of CR and subordinate to the Deputy Minister for Health Care, who would nominate him and call him off based on common recommendation of ČBK and ERC. The Head Hospital Chaplain would thus be recommended by ČBK and ERC from among the existing chaplains, so that chaplains from the Roman Catholic Church and one of the churches associated under ERC would take turns after stipulated periods of time. Head Hospital Chaplain would e.g. methodologically direct the individual chaplains, supervise the staffing of chaplain positions and their creation where they as yet do not exist, cooperate with health care facilities in introducing chaplaincy service, oversee the professional education of chaplains and organization of educational lectures on hospital chaplaincy for health care facilities, coordinate the organization of lifelong education courses for hospital chaplains, oversee chaplains' supervisions, etc. According to the consideration of the parties concerned the position of Deputy Head Hospital Chaplain could also be established, whose activity would also be directed by the Head Chaplain.

\subsection{Creating methodology for standardizing the processes associated with chaplains' activity}

Accredited or accreditation seeking health care facilities will have to (according to the degree of accreditation), if hospital chaplains become their employees, standardize, monitor, describe and evaluate all processes associated with the chaplains' activity. That can bring along both positive aspects and negative ones. For the health care facility the activity of the chaplain would thereby become reportable, controllable and searchable, since records should be part of patient documentation, which would be important not only from the 
point of view of accreditation, but also if the chaplains' work was to be financed from public health insurance. On the other hand, it need not be evident for some health care facilities what a standard concerning pastoral and spiritual care should contain and how to create it. Beside that the above mentioned standardization could bring considerable administrative load for the hospital chaplains, as they would be obliged to describe and record all their activities, which, especially in larger health care facilities in which only one chaplain is working, could present a certain problem. It is therefore a question whether the Ministry of Health Care could not in this context create a unified methodology containing the "necessary minimum" for the standardization of processes associated with the activity of hospital chaplains, so that health care facilities get an overview of what the standard in question must minimally contain, how to create it and fulfil it, and that hospital chaplains are not loaded by administrative work beyond the scope of requirements stated in this methodology.

\subsection{Hospital chaplain as condition of accreditation}

In the ever stronger competition environment many health care facilities are striving for accreditation according to the International Accreditation Standards, established by the Joint Commission International, which are the basis for accreditation of health care facilities worldwide. Accreditation is regarded as an effective means of evaluation and care quality management. One of the key standards that must unconditionally be met for the accreditation to be granted is standard PFR. 1.2.1., which states: "The hospital has created a procedure as part of which it satisfies the requirements of patients and their near ones for providing spiritual services or similar requirements issuing from the patients spiritual needs and religious beliefs." 43

Although this means that a health care facility striving for the above accreditation must ensure providing spiritual services, it does not yet necessarily assume the continuous presence of a hospital chaplain in the health care facility. The legislative regulation should therefore stipulate whether to meet the accreditation standards it is sufficient for the health care facilities to ensure spiritual service e.g. in the form of emergency visits of clerics on demand, or whether to meet the standard the presence of a hospital chaplain is necessary. Since health care facilities in the Czech Republic belong under different umbrella organizations, it is hardly possible to proceed in a unified way when introducing chaplaincy service, as it was e.g. in the army or prison service, and prescribe the presence of a hospital chaplain by law. Despite that the Ministry of Health Care could set down the continuous presence of a hospital chaplain as one of the conditions of granting a higher-degree accreditation. His presence could thus contribute not only to the meeting of the relevant standard, but also to increasing the prestige of the given health care facility.

\section{Conclusion}

In the last approximately five years introducing the service of hospital chaplains has seen great positive development and, following the service of military and prison chaplains, the service of hospital chaplains is also gradually becoming commonplace. It has been

43 Marie OPATRNÁ, Etické problémy v onkologii, pp. 85-86. 
possible to overcome the unsystematic and fragmentary character of the beginnings of spiritual care in hospitals and two umbrella organizations have been founded - associations of hospital chaplains associating hospital chaplains, which contribute to their systematic and coordinated education, guarantee and organize formational educational courses and allow for exchange of experience, inform of the work of hospital chaplains at their websites and thus help to spread awareness of the activity of hospital chaplains in health care and other facilities. The Protestant Theological Faculty of the Charles University in Prague and the Sts. Cyril and Methodius Faculty of Theology of the Palacký University in Olomouc organize as part of lifelong education courses the course Hospital Chaplain, which makes it possible to meet the qualification requirements of churches according to Supplement no. 1 to the Agreement on Spiritual Care in the Health Care System, as stated above.

As is evident from what has been said, the churches are making an effort to ensure that hospital chaplains get everywhere where their service is needed and that the work of hospital chaplains is well-qualified and their position equal to the position of their colleagues in the army or prison service, which would mean e.g. incorporating hospital chaplains in multidisciplinary teams, their participation in ethical commissions etc. But spiritual service in the health care system, unlike the departments above, as yet does not have the necessary legislative framework and legal grounding. Although negotiations with the present Minister of Health Care are taking place, there is as yet no particular, practical output from them. One can only hope that, like the former Minister of Health Care Heger, his present successor will also pay the necessary attention to the issue of spiritual care in his department.

With some overstatement one can say that hospital chaplaincy is in half-time. At sports events the players in second half-time usually try to improve the score and meet the expectations and resolutions that it had not been possible to fulfil in the first half-time. For the sphere of hospital chaplaincy it would certainly be advantageous if, due to the active attitude and cooperation of the Ministry of Health Care of CR, it is possible in its imaginary second halftime to attain such position of hospital chaplains in health care facilities as is held by their colleagues in the surrounding countries, where spiritual service had not been markedly restricted or discontinued by years of lasting unfreedom.

\title{
Hospital Chaplaincy in Half-Time
}

\begin{abstract}
The Christian churches, aware of their mission to serve persons in need, provide spiritual service, among others, in the army, the prison service and the police, and in the past few years also in the health care system. Beside army chaplains and prison chaplains, hospital chaplains are also becoming common. But the service of hospital chaplains as yet lacks the necessary legislative framework and legal grounding. The prepared law on non-medical workers should therefore secure an appropriate position to prison chaplains among other workers in health care, as it is in case of their colleagues in the army or the prison service.
\end{abstract}

Keywords: hospital chaplaincy, health care system, legislation 


\section{Contact}

Mgr. et Mgr. Jana Maryšková

University of Souht Bohemia, České Budějovice

Faculty of Theology, Department of Ethics, Psychology and Charity Work

Kněžská 8, 37001 České Budějovice

janamarys@seznam.cz 